\title{
SISTEM PENGEMBANGAN, PENGELOLAAN DAN FASILITAS LABORATORIUM PRODUKTIF AKUNTANSI DALAM MENINGKATAKAN KUALITAS KOMPUTER AKUNTANSI (PRODI AKUNTANSI FAKULTAS EKONOMI UMRAH)
}

\section{DEVELOPMENT, MANAGEMENT AND FACILITY SYSTEM OF ACCOUNTING PRODUCTIVE LABORATORY IN IMPROVING ACCOUNTING COMPUTER QUALITY (ACCOUNTING DEPARTMENT IN FACULTY OF ECONOMY AT UMRAH)}

\author{
Jack Febriand Adel ${ }^{1}$, Tumpal Manik ${ }^{2}$ \\ 1 Universitas Maritim Raja Ali Haji \\ 2Universitas Maritim Raja Ali Haji \\ tmanyk@gmail.com dan tmanik@umrah.ac.id
}

\begin{abstract}
ABSTRAK
Tujuan penelitian ini adalah untuk menganalisis dan memberikan solusi kelayakan fasilitas laboratorium produktif akuntansi fakultas Ekonomi UMRAH. Hasil penelitian ini adalah 1) Ruangan laboratorium akuntansi Fakultas Ekonomi UMRAH belum memenuhi standar sebagai laboratorium akuntansi dianalisis berdasarkan, fasilitas, keaslian aplikasi (software), sistem LAN dan kondisi ruangan, Analisis perubahan rangkaian posisi komputer cleint mahasiswa dan dosen. Analisis solusi pengembangan dan pengelolaan laboratorium akuntansi lebih utama pada penataan tempat komputer, Server, jaringan LAN dan instalasi komputer yang aman sehingga akan lebih efisien dan efektif digunakan selama proses belajar dan mengajar, sehingga dosen lebih mudah memantau proses dan hasil praktikum komputer akuntansi dalam ruang belajar laboratorium.
\end{abstract}

Kata kunci : Laboratorium akuntansi, pengembangan, pengelolaan dan fasilitas laboratorium

\begin{abstract}
The purpose of this study was to analyze and provide solutions to the feasibility of productive laboratory facilities for accounting for UMRAH Economics faculty. The results of this study are 1) The UMRAH Faculty of Economics accounting laboratory field does not meet the standards as an accounting laboratory analyzed based on facilities, authenticity of application (software), LAN system and room conditions, Analysis of changes in the position of cleint computer students and lecturers. Analysis of solution development and management of accounting laboratories is more important in structuring the place of computers, servers, LAN networks and safe computer installations so that it will be more efficient and effective to use during the learning and teaching process, so that lecturers will more easily monitor the process and results of accounting computer practicum in the study room laboratory.
\end{abstract}

Keywords : Accounting laboratory, development, management and laboratory facilities 


\section{PENDAHULUAN}

Laboratorium akuntansi sebagai media sarana dan prasarana pembelajaran untuk menyampaikan dan memberikan pemahaman tentang penerapan atas konsep-konsep akuntansi dalam praktik-praktik akuntansi dalam dunia bisnis nyata bagi para mahasiswa. Untuk mencapai tujuan laboratorium akuntansi ini, maka laboratorium akuntansi menyelenggarakan praktikumpraktikum dan pendidikan dan pelatihan (diklat), baik yang bersifat wajib mapun opsional. Disamping itu, laboratorium akuntansi bekerjasama dengan pihak-pihak terkait, seperti kantor akuntan publik, perusahaan, dan pemerintah daerah. Ini semua ditujukan untuk meningkatkan kualitas penyelenggaraan praktikum dan diklat yang diselenggarakan. Kegiatan praktikum di bidang akuntansi meliputi praktikum: akuntansi jasa, dagang, industri, komputer, pengauditan, perpajakan, dan metodologi penelitian akuntansi. Diklat yang dilakukan bersifat opsional, dalam arti kegiatan ini hanya ditujukan bagi mahasiswa yang berminat dan ingin mendalami bidang tertentu.

Tercapainya sistem pengembangan laboratorium produktif akuntansi yang efektif dan efisien jika diterapkan melalui pendekatan proses yaitu kegiatan atau sejumlah kegiatan apapun yang memakai sumber daya untuk mengubah masukan menjadi keluaran harus menyususn dan mengetahui proses yakni : menetapkan urutan dan interaksi proses-proses tersebut, menetapkan kriteria dan metode yang diperlukan, memastikan ketersediaan sumber daya dan informasi yang diperlukan di laboratorium, kemudian memantau, mengukur, dan menganalisis proses-proses yang ada di Laboratorium.

Pengelolaan laboratorium akuntansi bertujuan untuk pengembangan ilmu akuntansi secara pratik melalui aplikasi komputer akuntansi dalam rangka pengembangan, pengkajian, dan pengimplementasian bidang ilmu akuntansi, audit, pajak, dan bidang yang terkait dengan akuntansi. Sedangkan manfaat dari laboratorium akuntansi ini diharapkan akan menjalankan berbagai macam kegiatan, antara lain melakukan penelitian di bidang akuntansi, melakukan dan mengimplementasikan hasil penelitian dalam kebijakan akuntansi, melakukan studi lapangan, meningkatkan sumberdaya manusia dilingkungan internal maupun eksternal, melakukan seminasi hasil penelitian maupun hasil diskusi, mengadakan pelatihan dan konsultasi, melakukan kerjasama dengan pihak-pihak eksternal (pemerintah, perusahaan dan masyarakat) dalam rangka mengembangkan teori dan praktek akuntansi serta perpajakan.

Laboratorium akuntansi yang baik harus dilengkapi dengan berbagai fasilitas untuk memudahkan pemakaian laboratorium dalam melakukan aktivitasnya pada saat proses belajrmengajar. Pengelolaan laboratorium (Managemen Laboratory) adalah salah satu usaha dalam mengelola suatu laboratorium. Suatu laboratorium dapat dikelola dengan baik sangat ditentukan oleh beberapa faktor yang saling berkaitan satu dengan yang lainnya. Oleh karena itu manajemen laboratorium adalah suatu bagian yang tidak dapat dipisahkan dari kegiatan laboratorium sehari-hari.

Kelayakan fasilitas laboratorium produktif akuntansi didukung dengan ketersediaan infrastruktur laboratorium. Infrastruktur laboratorium ini meliputi sarana utama dan sarana pendukung, antara lain : 1) Sarana utama yakni mencakup bahasan tentang peralatan (komputer, aplikasi/software, meja komputer, kursi, jaringan LAN) lokasi laboratorium, konstruksi laboratorium dan sarana lain, termasuk pintu utama, pintu darurat, jenis meja kerja/pelataran, jenis atap, jenis dinding, jenis lantai, jenis pintu, jenis lampu yang dipakai, kamar penangas, jenis pembuangan limbah, jenis ventilasi, jenis AC, jenis tempat penyimpanan, kondisi laboratorium, dan se- 
bagainya. 2) Sarana Pendukung, yakni mencakup bahasan tentang ketersediaan energi listrik, alat komunikasi, dan pendukung keselamatan kerja seperti pemadam kebakaran, hidran.

Selain kelayakan fasilitas laboratorium produktif akuntansi, secara tekhnis, kelengapan software komputer akuntansi juga sebagai bagian dari pengembangan laboratorium komputer akuntansi, misalnya aplikasi MYOB Accounting yang menyajikan pembelajaran konsep dasar akuntansi hinga laporan keuangan dipraktikkan melalui setup perusahaan, saldo awal pembukuan, account (rekening), inventory, data pelanggan dan pemasok (supplier), penjualan dan piutang dagang, pembelian, hutang dagang, bank, time billing. Konsep materi ini menjadi satu bagian pengembangan laboratorium akuntansi, sehingga peneliti tertarik dan melakukan penelitian dengan judul "Sistem Pengembangan, Pengelolaan Dan Fasilitas Laboratorium Produktif Akuntansi Dalam Meningkatakan Kualitas Komputer Akuntansi Versi Myob Accounting".

Berdasarkan uraian latar belakang ditas, maka tujuan penelitian ini adalah antara lain: 1) menganalisis dan memberikan solusi sistem pengembangan laboratorium produktif akuntansi, 2) menganalisis dan memberikan solusi sistem pengelolaan laboratorium produktif akuntansi, 3) Untuk menganalisis dan memberikan solusi kelayakan fasilitas laboratorium produktif akuntansi fakultas Ekonomi UMRAH.

\section{LANDASAN TEORI}

\section{Sistem Pengembangan Laboratorium Produktif Akuntansi}

Sistem informasi merupakan sebuah alat atau sarana yang bertujuan untuk mengolah data menjadi informasi yang dapat dimanfaatkan oleh pengambil keputusan (Fahmi Hakam: 2016). Tujuan dari suatu sistem informasi adalah menciptakan suatu wadah komunikasi yang efisien dalam bidang bisnis. Sistem informasi berbasis internet merupakan sistem informasi yang memanfaatkan secara maksimal kegunaan dari komputer dan juga jaringan komputer. Selain itu, sistem informasi berbasis internet merupakan suatu sistem di mana interaksi manusia dan komputer menjadi faktor yang sangat penting.

Pengembangan laboratorium produktif akuntansi tujuannya adalah untuk meningkatkan aktivitas pembejalaran dalam mencapai hasil belajar yang dilakukan oleh dosen yang mengajar mata kuliah praktik di laboratorium akuntansi dengan mahasiswa baik di dalam ruang kelas perkuliahan maupun di laboratorium, di bengkel kerja, dan di kancah belajar lainnya yang terwujud dalam bentuk hasil belajar nyata yang dicapai oleh mahasiswa dalam satu semester, sehingga hasil pengembangan laboratorium produktif akuntansi untuk kegiatan praktek di laboratorium diharapkan dapat membantu para mahasiswa untuk lebih memahami dan mengerti konsep teori yang diberikan oleh dosen saat di kelas/ruang laboratorium.

Tercapainya sistem pengembangan laboratorium produktif akuntansi yang efektif dan efisien jika diterapkan melalui pendekatan proses yaitu kegiatan atau sejumlah kegiatan apapun yang memakai sumber daya untuk mengubah masukan menjadi keluaran. Karena itu, organisasi laboratorium harus mengetahui dan mengelola banyak proses yang saling berkaitan dan berinteraksi. Seringkali keluaran dari satu proses akan langsung menjadi masukan bagi proses berikutnya. Berkaitan dengan hal tersebut, organisasi harus mengetahui proses yang diperlukan untuk SMM dan aplikasinya di seluruh organisasi, antara lain : a) Menetapkan urutan dan interaksi proses-proses tersebut. b) Menetapkan kriteria dan metode yang diperlukan untuk memastikan bahwa baik operasional Laboratorium akuntansi maupun kendali proses-proses yang ada di laboratorium telah berjalan secara efektif. c) Memastikan ketersediaan sumber daya dan informasi yang diperlukan di laboratorium, untuk mendukung operasional dan pemantauan proses-proses 
yang ada di Laboratorium. d) Memantau, mengukur, dan menganalisis proses-proses yang ada di Laboratorium; serta mengimplementasikan tindakan yang diperlukan untuk mencapai hasil yang direncanakan dan perbaikan bekesinambungan dari proses-proses tersebut (Kemenkes. 2017).

\section{Sistem Pengelolaan Laboratorium Produktif Akuntansi}

Pengelolaan laboratorium akuntansi bertujuan untuk pengembangan ilmu akuntansi secara pratik melalui aplikasi komputer akuntansi dalam rangka pengembangan, pengkajian, dan pengimplementasian bidang ilmu akuntansi, audit, pajak, dan bidang yang terkait dengan akuntansi. Sedangkan manfaat dari laboratorium akuntansi ini diharapkan akan menjalankan berbagai macam kegiatan, antara lain melakukan penelitian di bidang akuntansi, melakukan dan mengimplementasikan hasil penelitian dalam kebijakan akuntansi, melakukan studi lapangan, meningkatkan sumberdaya manusia dilingkungan internal maupun eksternal, melakukan seminasi hasil penelitian maupun hasil diskusi, mengadakan pelatihan dan konsultasi, melakukan kerjasama dengan pihak-pihak eksternal (pemerintah, perusahaan dan masyarakat) dalam rangka mengembangkan teori dan praktek akuntansi serta perpajakan.

Pengelolaan laboratorium (Managemen Laboratory) adalah salah satu usaha dalam mengelola suatu laboratorium. Laboratorium yang baik harus dilengkapi dengan berbagai fasilitas untuk memudahkan pemakaian laboratorium dalam melakukan aktivitasnya. Suatu laboratorium dapat dikelola dengan baik sangat ditentukan oleh beberapa faktor yang saling berkaitan satu dengan yang lainnya.

Beberapa alat-alat laboratorium yang canggih, dengan staf profesional yang terampil belum tentu dapat berfungsi dengan baik, jika tidak didukung oleh adanya manajemen laboratorium yang baik. Oleh karena itu manajemen laboratorium adalah suatu bagian yang tidak dapat dipisahkan dari kegiatan laboratorium sehari-hari (Kemenkes RI, 2017). Pentingnya pengelolaan laboratorium mencakup beberapa hal yakni; a) pemeliharaan kelancaran penggunaan laboratorium, b) Menyediakan alat atau bahan yang diperlukan, c) Membuat format pinjaman, c) Pendokumentasian atau pengarsipan, d) Peningkatan mutu laboratorium.

Mencapai tujuan dari sistem pengelolaan laboratorium produktif akuntansi, maka diperlukan manajemen operasional laboratorium komputer akuntansi untuk mengelola laboratorium yang baik, harus dipahami perangkat-perangkat yang dikelola dalam manajemen laboratorium komputer akuantansi yaitu: 1) Tata ruang, 2) Alat yang baik dan terkalibrasi, 3) Infrastruktur, 4) Administrasi laboratorium, 5) Organisasi laboratorium, 6) Fasilitas pendanaan, 7) Inventarisasi dan keamanan, 8) Pengamanan laboratorium, 9) Disiplin yang tinggi keterampilan SDM, 10) Peraturan umum, 11) Penanganan masalah umum, 12) Jenis-jenis pekerjaan.

Semua perangkat diatas, jika dikelola secara optimal akan mendukung terwujudnya penerapan manajemen laboratorium yang baik. Dengan demikian manajemen laboratorium dapat dipahami sebagai suatu tindakan pengelolaan yang kompleks dan terarah, sejak dari perencanaan tata ruang sampai dengan perencanaan semua perangkat penunjang lainnya demi terpenuhinya kualitas operasional sebuah laboratorium.

\section{Kelayakan Fasilitas Laboratorium Produktif Akuntansi}

Kelayakan fasilitas laboratorium produktif akuntansi didukung dengan ketersediaan infrastruktur laboratorium. Infrastruktur laboratorium ini meliputi sarana utama dan sarana pendukung, antara lain : 1) Sarana utama yakni mencakup bahasan tentang peralatan (komputer, ap- 
likasi/software, meja komputer, kursi, jaringan) lokasi laboratorium, konstruksi laboratorium dan sarana lain, termasuk pintu utama, pintu darurat, jenis meja kerja/pelataran, jenis atap, jenis dinding, jenis lantai, jenis pintu, jenis lampu yang dipakai, kamar penangas, jenis pembuangan limbah, jenis ventilasi, jenis AC, jenis tempat penyimpanan, kondisi laboratorium, dan sebagainya. 2) Sarana Pendukung, yakni mencakup bahasan tentang ketersediaan energi listrik, alat komunikasi, dan pendukung keselamatan kerja seperti pemadam kebakaran, hidran dsb.

Penelitian terdahulu mengenai pengaruh motivasi belajar, computer attitude, dan fasilitas laboratorium akuntansi terhadap prestasi belajar komputer akuntansi MYOB telah dilakukan oleh Merdiana Era Safitri (2015), Hasil penelitian menunjukkan fasilitas laboratorium akuntansi berpengaruh terhadap prestasi belajar komputer akuntansi MYOB.

Wulandari (2015), melakukan penelitian dengan judul Pengaruh computer knowlegde, computer attitude, dan Fasilitas Laboratorium Komputer Terhadap Hasil Belajar Komputer Akuntansi Siswa Kelas XI Akuntansi SMK Negeri 1 Surabaya. Hasil penelitian menunjukkan adanya pengaruh signifikan antara computer knowledge, computer attitude, dan fasilitas laboratorium komputer terhadap hasil belajar komputer akuntansi. Hasil penelitian tersebut berbeda dengan hasil penelitian Cahyono (2010) yang menunjukkan ketersediaan fasilitas tekhnologi informasi tidak mempunyai pengaruh terhadap sikap mahasiswa dalam menggunakan komputer akuntansi.

Menurut The Liang Gie dalam Budiarti (2011: 27), fasilitas belajar merupakan persaratan yang meliputi keadaan sekeliling tempat belajar dan keadaan jasmani mahasiswa, meliputi ruang tempat belajar, penerangan cukup, buku-buku pegangan dan peralatan lain". Fasilitas belajar dalam hal ini merupakan faktor yang berpengaruh dari luar siswa terhadap hasil belajar. Munir (2012: 24) mengatakan "perwujudan integrasi pada sarana prasarana dalam fasilitas belajar yang berhubungan dengan kebutuhan berbasis komputer (multimedia), yaitu pada laboratorium komputer". Hal ini juga dilakukan dalam mata kuliah praktik komputer akuntansi di laboratorium komputer pendidikan akuntansi Universitas Muhammadiyah Surakarta sebagai perwujudan pembelajaran akuntansi berbasis komputerisasi.

Menurut sardiman (2011), Hasil belajar merupakan perubahan tingkah laku atau penampilan, dengan serangkaian kegiatan misalnya dengan membaca, mengamati, mendengarkan, meniru dan lain-lain. Jadi belajar akan membawa suatu perubahan pada individu-individu yang belajar. Perubahan tidak hanya dari penambahan ilmu pengetahuan namun juga dapat membentuk kecakapan, ketrampilan, sikap, pengertian, harga diri, minat, watak, penyesuaian diri. Jelasnya menyangkut segala aspek organisme dan tingkah laku pribadi seseorang.

Kualitas pembelajaran komputer akuntansi menjadi bagian dari keberhasilan suatu sistem informasi akuntasi yang diaplikasikan dalam pembelajaran komputer akuntansi dapat diukur berdasarkan output atau kualitas informasi yang dihasilkan (Manik, 2016). Kualitas informasi yang dihasilkan berdasarkan rangkaian ataupun proses penyusunan sistem tersebut termasuk proses penyusunan dan pembuatan sistem.

Memperoleh kualitas pembelajaran komputer akuntansi Versi MYOB Accounting tergantung pada tiga faktor utama, yaitu pertama; Media/alat pembelajaran (ketersediaan alat belajar seperti komputer, aplikasi/software, jaringan) tersedia berdasarkan analisis dan kajian yang tepat, kedua; sumber pembelajaran (buku atau diktat praktikum) sesuai dengan permintaan dunia kerja. ketiga; Kualitas pendidik (Dosen) memiliki pengetahuan tentang akuntansi, teknologi informasi dan sistem informasi akuntansi dan komputer akuntansi 


\section{METODOLOGI PENELITIAN}

\section{Jenis dan Spesifikasi Penelitian}

Jenis penelitian ini menggunakan metode kualitatif dan kuantitatif. Pendekatan metode kualitatif untuk memperoleh pemahaman makna penelitian, menyajikan data apa-adanya serta menginterpretasikan korelasi sebagai faktor sistem pengembangan, pengelolaan dan fasilitas laboratorium produktif akuntansi dalam meningkatakan kualitas komputer akuntansi versi Myob Accounting di Fakultas Ekonomi UMRAH). melalui berbagai sudut pandang atau proses pengambilan data dari kondisi yang sedang berlangsung dengan maksud untuk mencari, menemukan dan menyusun sistem pengembangan, pengelolaan dan fasilitas laboratorium produktif akuntansi

\section{Lokasi Tempat dan Waktu Penelitian}

Penelitian ini memilih lokasi di Program Studi Akuntansi Fakultas Ekonomi Universitas Maritim Raja Ali Haji (UMRAH) Kota Tanjungpinang. Waktu proses pelaksanaan penelitian dilakukan selama 8 (delapan) bulan, yaitu mulia bulan April sampai dengan Desember 2018, sesuai periode pengajuan penelitian Skema Penelitian Laboratorium dan Keahlian Dosen

\section{Sumber Data Penelitian}

Data yang digunakan dalam penelitian ini dapat dikelompokkan menjadi 2 (dua) jenis, yaitu : 1) Data Primer; data-data yang diperoleh secara langsung kelapangan lokasi penelitian melalui survei, observasi, interview atau wawancara terstruktur yang berhubungan dengan tujuan penelitian ini yang menjadi sumber informasi. 2) Data Sekunder; data yang diambil dari Kepala Laboratorium, dosen pengajar di laboratorium akuntansi dan mahasiswa yang sedang atau telah lulus mata kuliah komputer akuntansi, termasuk berupa data - data stastistik, peta dan gambar - gambar yang relevan dan terkait dengan penelitian ini berupa data arsip, data laporan dan data melalui study kepustakaan yakni data dari dokumen-dokumen.

\section{Teknik Pengumpulan Data}

Tujuan teknik pengumpulan data dilakukan peneliti adalah untuk melengkapi informasi dan sumber data-data yang dibutuhkan selama pengolahan data-data penelitian, baik data utama maupun data pendukung yakni data yang bersifat primer maupun sekunder. Memperoleh data yang sesuai dengan rumusan masalah dan tujuan penelitian ini, maka teknik pengumpulan dilakukan peneliti menggunakan 5 (lima) teknik pengumpulan data, antara lain : 1) Observasi; Observasi merupakan salah satu teknik pengumpulan data yang tidak hanya mengukur sikap dari responden (wawancara dan angket) namun juga dapat digunakan untuk merekam berbagai fenomena yang terjadi (situasi, kondisi). Dalam observasi ini, peneliti secara langsung terlibat dalam kegiatan sehari-hari orang atau situasi yang diamati sebagai sumber data. 2) Angket/kuisioner; Angket/kuesioner adalah teknik pengumpulan data yang dilakukan dengan cara memberikan seperangkat pertanyaan atau pernyataan kepada orang lain yang dijadikan responden untuk dijawab, tujuan pertanyaan yang diberikan kepada responden untuk menggali data sesuai dengan rumusan masalah dan tujuan penelitian. 3) Wawancara; Wawancara meru- 
pakan teknik pengumpulan data yang dilakukan melalui tatap muka dan tanyajawab langsung antara pengumpul data maupun peneliti terhadap narasumber atau sumber data. 4) Studi Kepustakaan; suatu bentuk pengumpulan data melalui buku yang sesuai dengan penelian atau literatur, hasil penelitian terdahulu.

\section{Populasi dan Sampel Penelitian}

Populasi penelitian ini adalah Fakultas Ekonomi UMRAH sedangkan sampel terdiri dari Kepala Laboratorium, Mahasiswa, Peralatan Laboratorium Akuntansi, Standar Operasioanal penggunaan Laboratorium Akuntansi

\section{Metode Analisis Data Penelitian}

Penelitian ini menggunakan pendekatan penelitian dan pengembangan (R\&D). Prosedur penelitian yang digunakan mengacu design and development research menurut Borg and Gall yang meliputi 8 (delapan) tahap pengembangan yaitu : 1) Research and information collecting, 2) Planning, 3) Develop preliminary form of product, 4) Preliminary field testing, 5) Main product revision, 6) Main field testing, 7) Operational product revision, 8) Operational field testing.

\section{HASIL DAN PEMBAHASAN}

\section{Analisis Sistem Pengembangan Laboratorium Produktif Akuntansi}

Lokasi dan posisi komputer tersusun laboratorum fakultas ekonomi berbentuk baris dalam 4 (empat) baris, namun untuk memaksimalkan proses belajar mengajar, kami menyusun model komputer client mahasiswa dengan komputer dosen seperti gambar dibawah ini.

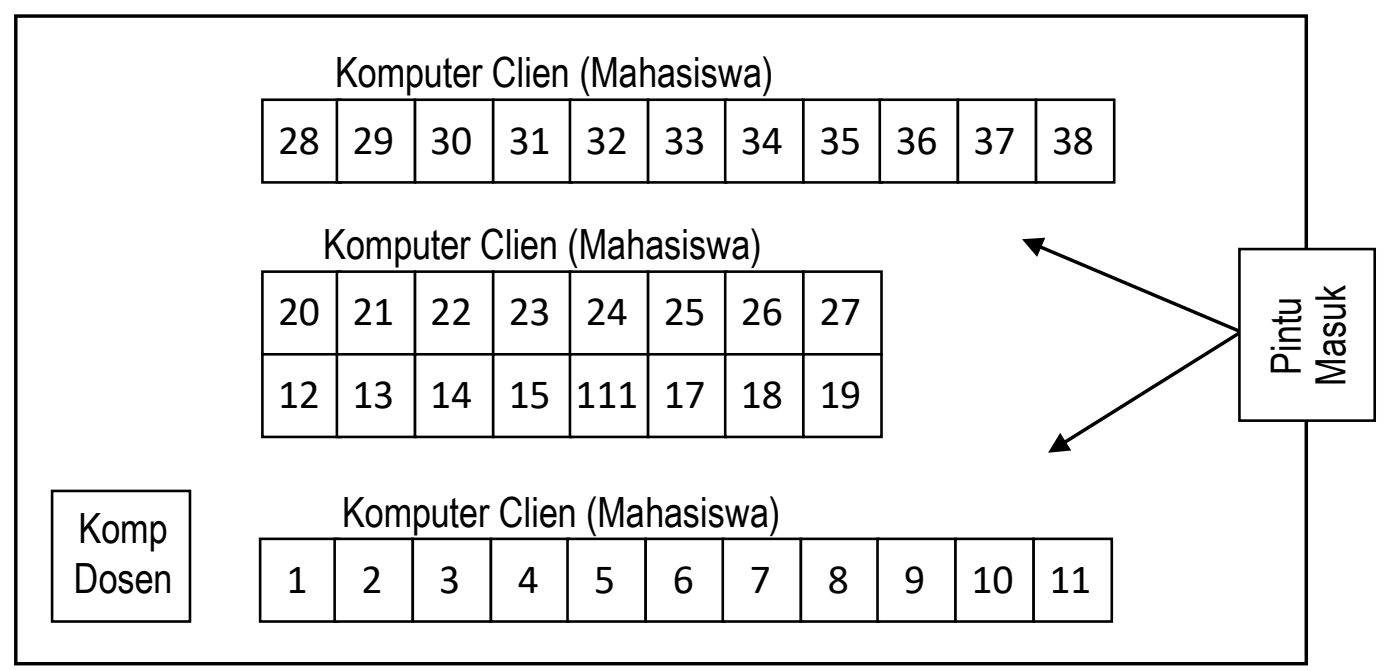

Gambar 1. Model Lama dan Analisis

Analisis gambar 1. merupakan kondisi laboratorium akuntansi fakultas ekonomi Universitas Maritim Raja Ali Haji pada saat penelitian ini dilakukan. Kondisi jaringan dan posisi komputer client untuk mahasiswa belum terusun dan adanya tumpang-tindih jaringan LAN dan kabel yang belum tertata dengan baik, termasuk intalasi jaringan listrik belum tertata dengan sempurna, hal ini disebabkan karena sistem dan tata letak komputer tidak sejajar dengan server LAN. 
Solusi pengembangan laboratorium akuntansi Fakultas Ekonomi UMRAH untuk mengatasi permasalahan dalam laboratorium akuntansi Fakultas Ekonomi UMRAH, peneliti telah menyusun rangakain sebagai pengendalian dan sistem pengembangan laboratorium produktif akuntansi sebagai rangkaian pengelolaan posisi dan latak komputer client mahasiswa dan dosen sebagai berikut :

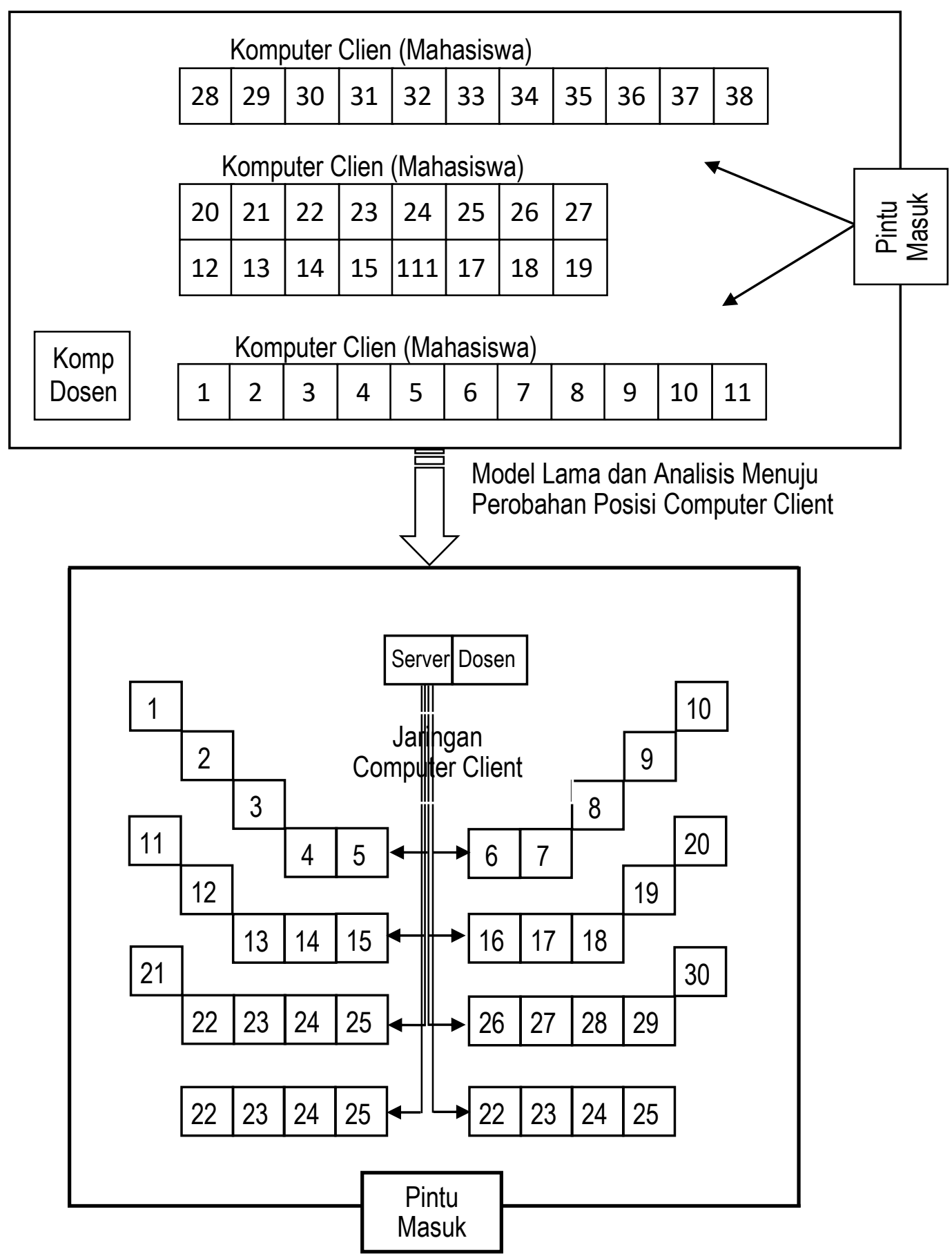

Gambar 2. Perubahan Rangkaian Posisi Komputer Cleint Mahasiswa dan Dosen

Analisis perubahan rangkaian posisi komputer cleint mahasiswa dan dosen dalam gambar 2 diatas lebih efisien digunakan untuk proses belajar dan mengajar, sebab dalam rangakain yang 
baru Dosen lebih mudah memantau proses dan hasil praktikum komputer akuntansi dalam ruang belajar laboratorium, termasuk rangkaian jaringan LAN dan instalasi listrik lebih tertata. Jika komputer klient rusak, maka lebih mudah untuk memperbaiki unit komputer.

Gambar rangkaian dengan komputer dalam laboratorium akuntansi untuk jaringan LAN dan Listrik pada rangkaian komputer cleint mahasiswa dan dosen seperti gambar di bawah ini.

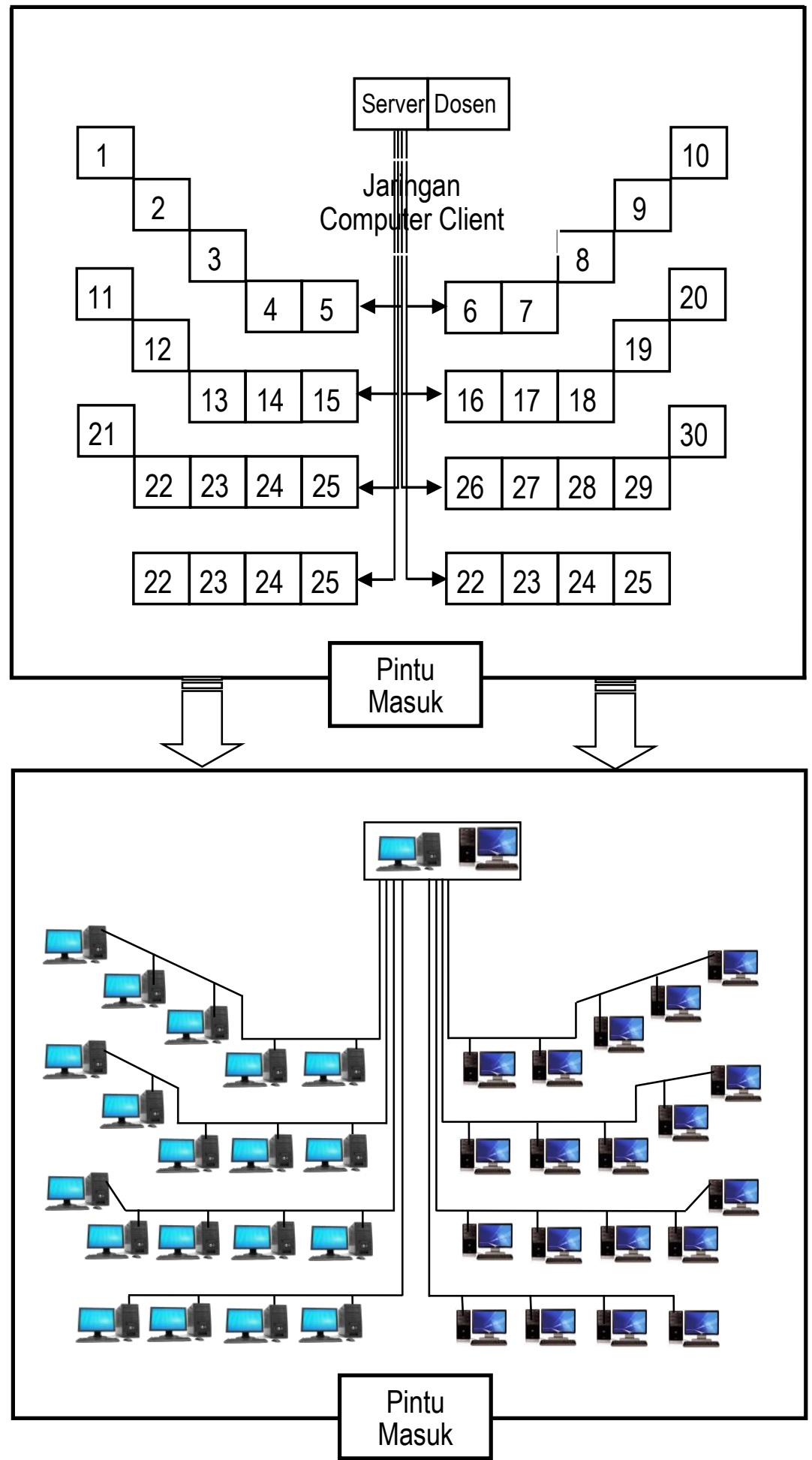

Gambar 3. Perubahan Rangkaian Komputer Cleint Mahasiswa dan Dosen 
Siklus proses dan strategi analisis sistem pengembangan laboratorium produktif akuntansi digambarkan dibawah ini sebagai brand awareness yang terdiri dari empat tingkatan yaitu: 1) System Planning (Perencanaan Sistem), 2) System Analysis (Analisis Sistem), 3). System Design (Perancangan Sistem), 4). System Implementation( Implementasi Sistem) dan 5). Sytem Support (System Pendukung)

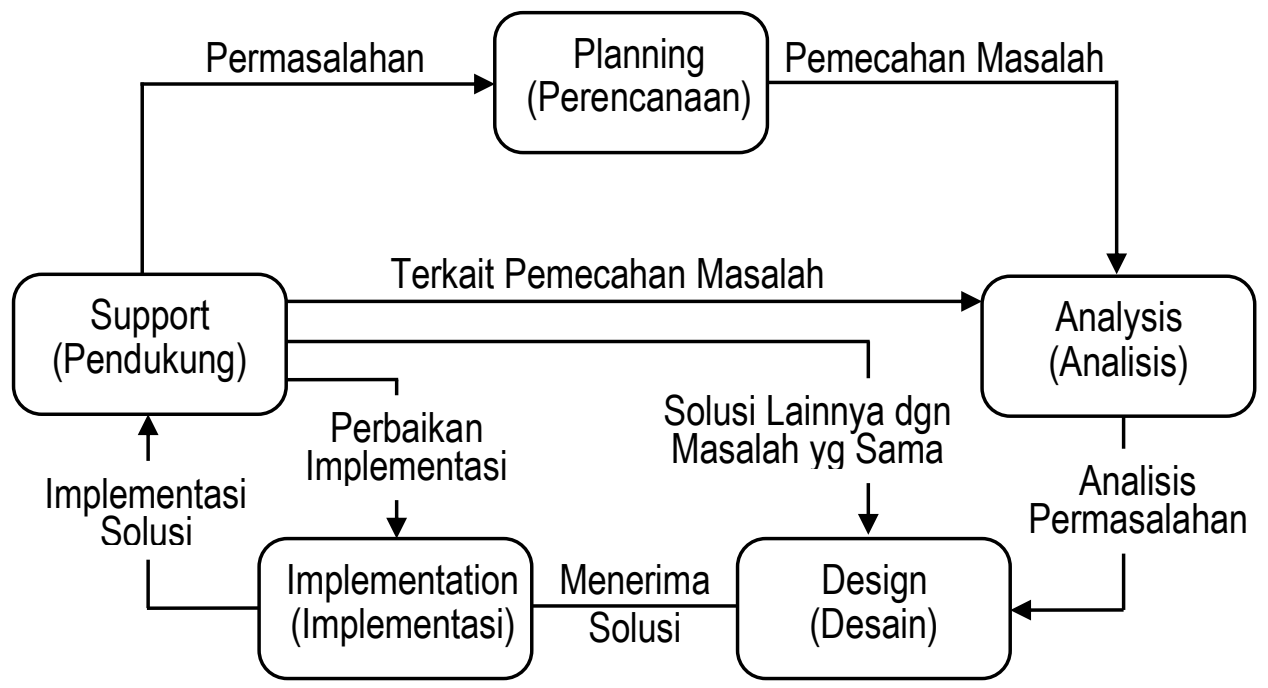

Gambar 4. Tahapan Sistem Siklus Pengembangan

\section{Analisis Sistem Pengelolaan Laboratorium Produktif Akuntansi}

Pengembangan pengelolaan laboratorium komputer akuntansi dilakukan dibeberapa kegiatan pengelolaan diantaranya: penegasan kembali pemberlakuan tata tertib laboratorium bagi mahasiswa/i dan pemberian sanksi yang tegas demi kelancaran dan keamanan pengguna laboratorium, perluasan ruang laboratorium yang secara tidak langsung juga menambah kebutuhan alat dan bahan, penjadwalan yang tepat, pengawasan yang lebih dengan memberikan tanggung jawab pengawasan oleh kepala laboratorium tapi juga kepada seluruh warga mahasiswa prodi akuntansi yang menggunakan laboratorium untuk proses belajar dan mangajar agar memiliki rasa kepemilikikan terhadap sarana dan prasarana laboratoruim akuntansi.

Mencapai tujuan dari sistem pengelolaan laboratorium produktif akuntansi, maka diperlukan manajemen operasional laboratorium komputer akuntansi untuk mengelola laboratorium yang baik, harus dipahami perangkat-perangkat yang dikelola dalam manajemen laboratorium komputer akuantansi, Kesimpulan pengelolaan laboratorium komputer akuntansi meliputi:

1) Perencanaan (pleanning) kegiatan laboratorium; menyusun jadwal perkuliahan sesuai dengan mata kuliah praktik akuntansi

2) Penataan laboratorium; menata ruangan laboratorium komputer akuntansi yakni penataan meja dan komputer, jaringan LAN dan instalasi listrik dan lemari menyimpan hasil praktikum.

3) Inventarisasi dan dokumnentasi laboratorium; membuat daftar inventaris laboratorium dan mencatat penggunaan laboratorium termasuk daftar komputer yang rusak

4) Pengoperasian peralatan dan penggunaan komputer; pengoperasian atau penggunaan komputer berdasarkan SOP penggunaan laboratorium kompurter akuntansi

5) Perawatan peralatan dan bahan; melakukan perawatan peralatan laboratoruim secara berkala ataupun setiap saat penggunakan peralatan dalam laboratorium untuk mengurangi tingkat kerusakan. 
6) Pengevaluasian sistem kerja laboratorium; kepala laboratorium wajib mengevaluasi dosen yang menggunkan peralatan dan komputer dan apabila ditemukan permasalahan segera dicari solusi agar kegiatan proses belajar mengajar tidak tertunda dan dapat mencapi tujuan pengajaran

7) Pengembangan kegiatan laboratorium, pengembangan laboratorum dilalakun untuk pengembngan fisik (computer) dan pengembangan aplikasi komputer yang digunakan termasuk pengembngan Sumber Daya Manusia pengguna laboratorum komputer akuntansi.

Manfaat pengelolaan laboratorium komputer akuntansi diantaranya: 1) memudahkan pengadaan dan pengecekan alat dan perlenglapan; 2) mengefisiensikan penggunaan budget; 3) memperlancar pelaksanaan praktikum; 4) memudahkan membuat laporan pertanggungjawaban dan 5) membantu dalam hal akreditasi laboratorium / program studi, Sedangkan analisis persentasi sistem pengelolaan laboratorium produktif akuntansi diuraikan dalam tabel dibawah ini.

Tabel 1. Analisis Sistem Pengelolaan Laboratorium Produktif Akuntansi

\begin{tabular}{clc}
\hline No & \multicolumn{1}{c}{ Prosedur dan Sistem Pengelolaan } & Persentase \\
\hline 1 & Tata ruang & $10 \%$ \\
2 & Lokasi/Posisi Komputer & $10 \%$ \\
3 & Infrastruktur (Kapasitas Komputer, LAN, Listrik) & $30 \%$ \\
4 & Administrasi laboratorium & $5 \%$ \\
5 & Organisasi laboratorium (Manajemen) & $5 \%$ \\
7 & Inventarisasi dan Perawatan dan keamanan & $10 \%$ \\
9 & Disiplin yang tinggi keterampilan SDM & $15 \%$ \\
10 & Peraturan umum & $5 \%$ \\
11 & Penanganan masalah umum & $10 \%$ \\
\hline & Jumlah & $100 \%$ \\
\hline
\end{tabular}

Tabel 2. Hasil Analisis Kondisi Laboratorium Akuntansi (Praktik Komputer Akuntansi)

\begin{tabular}{clccc}
\hline No & \multicolumn{1}{c}{ Prosedur dan Sistem Pengelolaan } & $\begin{array}{c}\text { Target } \\
\text { Capaian } \\
\text { Nilai }\end{array}$ & $\begin{array}{c}\text { Reaslisasi } \\
\text { Capaian } \\
\text { Nilai }\end{array}$ & Kekurangan \\
\hline 1 & Tata ruang & $10,00 \%$ & $7,00 \%$ & $-3,00 \%$ \\
2 & Lokasi/Posisi Komputer & $10,00 \%$ & $7,00 \%$ & $-3,00 \%$ \\
3 & Infrastruktur (Kapasitas Komputer, LAN, Listrik) & $30,00 \%$ & $25,00 \%$ & $-5,00 \%$ \\
4 & Administrasi laboratorium & $5,00 \%$ & $2,00 \%$ & $-3,00 \%$ \\
5 & Organisasi laboratorium (Manajemen) & $5,00 \%$ & $2,00 \%$ & $-3,00 \%$ \\
7 & Inventarisasi dan Perawatan dan keamanan & $10,00 \%$ & $5,00 \%$ & $-5,00 \%$ \\
9 & Disiplin yang tinggi keterampilan SDM & $15,00 \%$ & $8,00 \%$ & $-7,00 \%$ \\
10 & Peraturan umum & $5,00 \%$ & $4,00 \%$ & $-1,00 \%$ \\
11 & Penanganan masalah umum & $10,00 \%$ & $6,00 \%$ & $-4,00 \%$ \\
\hline & Jumlah & $100,00 \%$ & $66,00 \%$ & $-34,00 \%$ \\
\hline
\end{tabular}


Tabel 3. Hasil analisis kondisi Labbor

\begin{tabular}{cll}
\hline No & \multicolumn{1}{c}{ Prosedur dan Sistem Pengelolaan } & \multicolumn{1}{c}{ Keterangan } \\
\hline 1 & Tata ruang & Perlu dilakukan penantaan \\
2 & Lokasi/Posisi Komputer & Compter Client tidak dirawat \\
3 & Infrastruktur (Kapasitas Komputer, LAN, Listrik) & Intallasi listrik kurang aman \\
4 & Administrasi laboratorium & Perlu menambah pranata Lab \\
5 & Organisasi laboratorium (Manajemen) & Manajemen kurang maksimal \\
7 & Inventarisasi dan Perawatan dan keamanan & Inventaris belum terkontol \\
9 & Disiplin yang tinggi keterampilan SDM & Disiplin agar ditingkatkan \\
10 & Peraturan umum & Peraturan umum perlu dibuat \\
11 & Penanganan masalah umum & Kurang maksimal \\
\hline
\end{tabular}

Standar sarana dan prasarana sebagai fasiltas Laboratorium komputer akuntansi, terdiri dari :

1) Komputer Cleint Mahasiswa; Hardrisk 5000 GB Processor : Intel (R) Core ${ }^{\mathrm{TM}}$ i5-512 RAM : $4,2 \mathrm{~GB}$

2) UPS; Pengendali arus listrik

3) Komputer Server dan Dosen

4) Hardrisk 6000 GB Processor : Intel (R) Core ${ }^{\mathrm{TM}}$ i5-512 RAM : 4,2 GB

5) Kursi Keja Komputer Cleint Mahasiswa dan Dosen; Kuat, stabil, aman, dan mudah dipindahkan. Ukuran memadai untuk bekerja dengan nyaman

6) Printer; harus Conecting semua LAN, (6) Tempat sampah; Dibelakan (kiri dan kan)

7) Air Condition (AC); 4 unit AC 1,5 Peka, agar kondisi ruangan tetap dingin.

Perangkat Sistem Operasional/Penggunaan Laboratorium Komputer Akuntansi dan ketersediaan Pengelolaan laboratorium agar memiliki SOP, antara lain :

1) SOP Pemakaian Laboratorium

2) SOP Setelah perkuliahan selesai

3) SOP Perawatan dan penggajuan perlatan lanboratorium

4) SOP Peminjaman Laboratorium

\section{Analisis Kelayakan Fasilitas Laboratorium Produktif Akuntansi}

Analisis kelayakan fasilitas laboratorium produktif akuntansi Fakultas Ekonomi UMRAH menggunakan Aplikasi Myob Accounting, dihitung berdasarkan hasil pengamatan peneliti. Beberapa elemen-elemen solusi pengelolaan laboratorium akuntansi di Fakultas Ekonomi Universitas Maritim Raja Ali Haji, anatara lain :

1. Luas Ruangan Komputer Akuntansi

Jenis, Rasio dan Deskripsi Prasarana Laboratorium Komputer Akuntansi :

Jarak setiap meja komputer cleint $\quad=1,5 \mathrm{~m}^{2} \times 1,5 \mathrm{~m}^{2}=3 \mathrm{M}^{2}$

Jumlah mahasiswa $\quad=38$ Orang

Luas meja komputer cleint mahasiswa $=38 \times 3 \mathrm{~m}=114,0 \mathrm{~m}$

Jarak/Luas space cleint mahasiswa $=5 \times 3 \mathrm{~m}=15,0 \mathrm{~m}$

Laus Ruangan minimal $\quad=129,0 \mathrm{~m}$

Apabila jumlah mahasiswa 38 orang, maka luas ruangan komputer minimal 129 meter, 


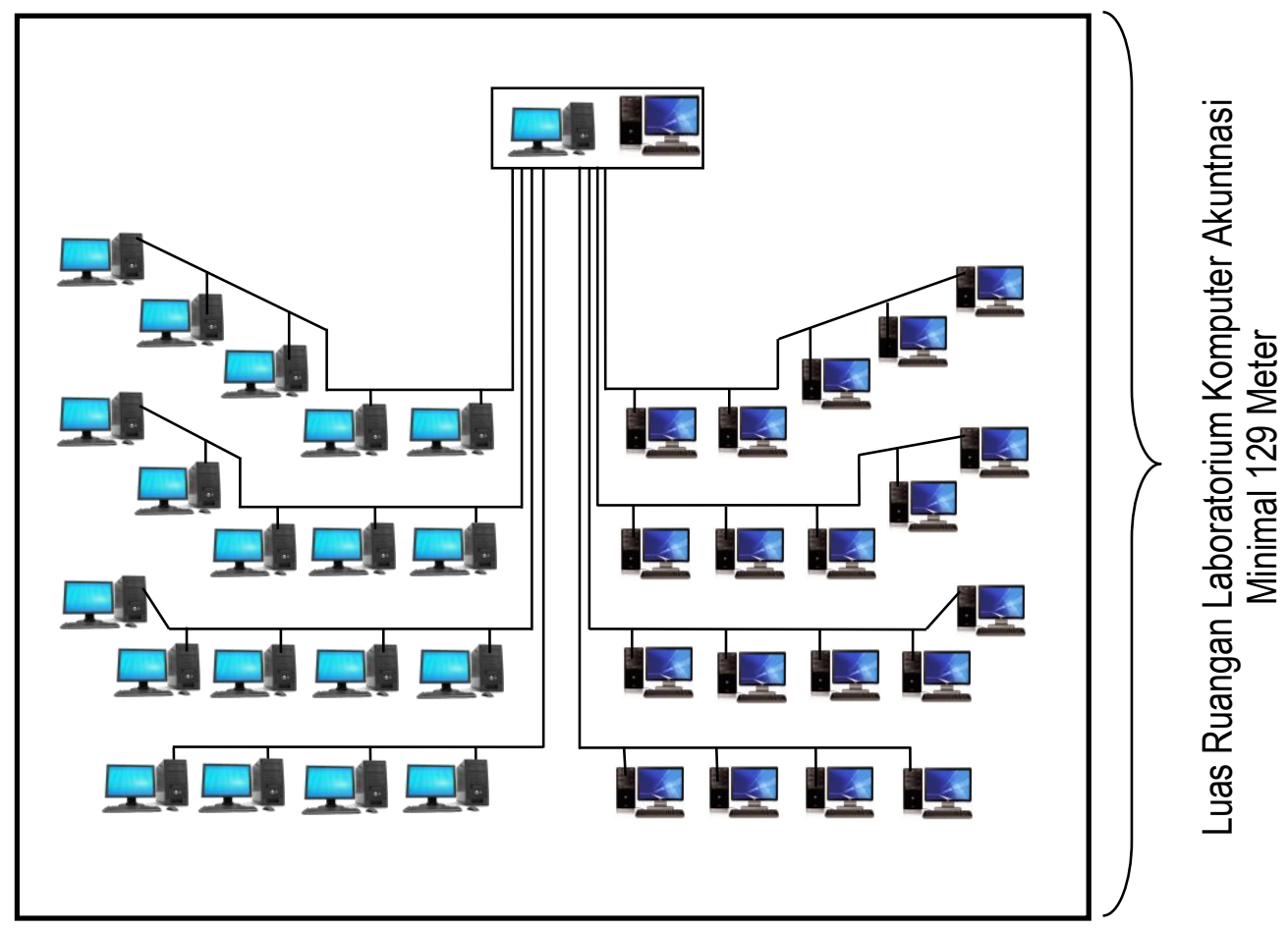

\section{KESIMPULAN DAN REKOMENDASI KEBIJAKAN}

\section{Kesimpulan}

Berdasarkan hasil analisis yang telah dilakukan peneliti, ada bebera kesimpulan yang dapat disimpulan dalam lapora kemajuan ini, antara lain :

1. Ruangan laboratorium akuntansi Fakultas Ekonomi UMRAH belum memenuhi standar sebagai laboratorium akuntansi dianalisis berdasarkan, fasilitas, keaslian aplikasi (software), sistem LAN dan kondisi ruangan

2. Lokasi dan posisi komputer tersusun laboratorum fakultas ekonomi berbentuk baris dan 4 (empat) baris, namun untuk memaksimalkan proses belajar mengajar perlu disusun kembali model komputer client mahasiswa dengan komputer dosen.

3. Dalam meningkatkan kualitas komputer akuntansi, maka peneliti akan menyusun kembali analisis sistem pengembangan kualitas komputer akuntansi

\section{Rekomendasi Kebijakan}

Sistem intalasi dan posisi komputer dalam laboratium bentuk baris dan berfokus pada pusat server. Namun setelah kami cek langsung fisik dan kondisi jaringan LAN server tidak berfungsi dengan baik, termasuk connecting receiver wifi tidak berfungsi dengan baik dari komputer, hal ini karena fungsi dan tangungjawab kepala laboratorium FE UMRAH tidak berjalan dengan baik, ditambah sistem pengendalian dari manajemen pimpinan Fakultas Ekonomi kurang maksimal, pada hal laboratorium khususnya mata kuliah komputer akuntansi wajib ditingkatkan, karena keahlian mahasiswa jurusan akuntansi salah satau adalah memiliki kompetensi komputer akuntansi. Untuk meningkatkan mutu dan kualitas alumni prodi akuntanasi khusunya komputer akuntnasu maka diperlukan perbaikan fasiltas sebagai sarana dan prasarana dasar laboratorium komputer akuntansi, termasuk system jaringan LAN dan instalasi lisatrik yang aman. 


\section{DAFTAR PUSTAKA}

Era, Safitri Merdiana. 2015. Pengaruh motivasi belajar, computer attitude, dan fasilitas laboratorium akuntansi terhadap prestasi belajar komputer akuntansi MYOB kelas XI Akuntansi SMK PGRI Batang. Jurnal Pendidikan Akuntansi. Vol 02, №. 01

Budiarti, L. Rahayu. 2011. Pengaruh Persepsi Mahasiswa Atas Kemampuan Dosen Dlam Pengelolaan Kelas dan Fasilitas Belajar Terhadap Hasil Belajar Kewirausahaan Pada Mahasiswa Pendidikan Ekonomi Akuntansi Universitas Mhammadiyah Surakarta Tahun Ajaran 2010/2011. Skripsi: Pendidikan Ekonomi Akuntansi. Universitas Muhammadiyah Surakarta.

Kemenkes RI. 2017. Aplikasi Sistem Informasi dan Manajemen Laboratorium

Manik, Tumpal. 2016. Sistem Informasi Akuntansi. UMRAH PRESS.

Manik, Tumpal. 2017. Komputer Akuntansi, "Perspektif Praktik dan Studi Kasus". UMRAH PRESS.

Munir. 2012. Multimedia: Konsep dan Aplikasi Dalam Pendidkan. Bandung: CV.Alfabeta.

Sardiman. A.M., 2011. Interaksi dan Motivasi Belajar Mengajar. Jakarta, Rajawali Pers.

Triandi dan Budhiharni. 2015. Penerapan Komputer Akuntansi (Myob) Untuk Meningkatkan Kualitas Informasi Laporan Keuangan Pada CV. Khesena. STIE Kesatuan.

Wulandari, Novi. 2015." Pengaruh Computer Knowledge, Computer Attitude, Dan Fasilitas Laboratorium Komputer Terhadapp Hasil Belajar KomputerrAkuntansi SiswasKelas XI Akuntansi SMK Negeri 1 Surabaya. Jurnal Akuntansi 